\title{
Satellite Data and Epidemic Cartography: A Study of the Relationship Between the Concentration of $\mathrm{NO}_{2}$ and the COVID-19 Epidemic
}

\author{
Gianmarco Pignocchino (D), Alessandro Pezzoli (D), and Angelo Besana ${ }^{(凶)}(\mathbb{D}$ \\ Interuniversity Department of Regional and Urban Studies and Planning, Politecnico and \\ University of Turin, Turin, Italy \\ gianmarco.pignocchin@edu.unito.it, alessandro.pezzoli@polito.it, \\ angelo.besana@unito.it
}

\begin{abstract}
Satellite data are widely used to study the spatial component of epidemics: to monitor their evolution, to create epidemiological risk maps and predictive models. The improvement of data quality, not only in technical terms but also of scientific relevance and robustness, represents in this context one of the most important aspects for health information technology that can make further significant and useful progress in monitoring and managing epidemics. In this regard, this paper intends to address an issue that is not always adequately considered in the use of satellite data for the creation of maps and spatial models of epidemics, namely the preliminary verification of the level of spatial correlation between remote sensing environmental variables and epidemics. Specifically, we intend to evaluate the contribution of exposure to the pollutant nitrogen dioxide $\left(\mathrm{NO}_{2}\right)$ on the spatial spread of the virus and the severity of the current COVID infection.
\end{abstract}

Keywords: Satellite data $\cdot$ Nitrogen dioxide $\left(\mathrm{NO}_{2}\right) \cdot$ COVID-19

\section{Introduction}

Satellite data, due to their capacity to guarantee constant and increasingly detailed observation, have long been permanently used to monitor and study spatial patterns and the spread of epidemics, in particular with respect to those variables that are believed to determine or favor the emergence and development of diseases, such as environmental conditions, distribution of causative agents and socio-demographic characteristics of human populations $[8,18,20,43]$. In particular, the combination of derived field data, statistical variables and satellite data is a fundamental element for building epidemiological risk maps and predictive models $[1,25]$. Moreover, the current pandemic emergency has highlighted the need to develop and implement such tools not only in the so-called developing countries, as has prevailed so far, but also in the more advanced 
countries, which have found themselves completely fragile with respect to such calamities and unprepared in the prevention and response measures, although such a danger was somewhat predictable [24, 42].

In the context of epidemic cartography, this contribution intends to deal in operational terms with an issue not always adequately considered in the use of satellite data for the creation of maps and spatial models of epidemics, i.e. the preliminary verification of the level of spatial correlation between remote sensing environmental variables and epidemics [19,37]. More precisely, we intend to evaluate the contribution of exposure to the pollutant nitrogen dioxide $\left(\mathrm{NO}_{2}\right)$ on the spatial spread of the virus and on the severity of the current COVID-19 infection, in order to confirm the operational validity of the use of this environmental variable in the related epidemic cartography. The improvement of data quality, not only in technical terms but also of scientific relevance and robustness, is in fact one of the most important aspects for health information technology that can make further significant and useful progress in monitoring and managing epidemics [20, 39].

As it is known, Northern Italy was the area most affected by the first wave of the COVID-19 epidemic. The great speed and intensity with which COVID-19 disease has spread to these regions has prompted the hypothesis, in some preliminary studies, that high levels of pollution may play a role in viral transmission and in determining the severity of the infection [4, 6, 28, 35, 38, 40]. In fact, Northern Italy is considered as one of the most heavily polluted area in Europe in terms of smog and air pollution [2, 26,33 ] because it is characterized by a high concentration of densely populated urban areas, as well as by a strong presence of industrial activities. In addition, the particular closed geomorphological conformation of Po Valley prevents pollutants re-circulation and release with their consequent stagnation due to the low ventilation [16].

\section{Materials and Methods}

We worked on data from the Northwest regions and the first wave of the epidemic.

\subsection{Environmental Data}

Pollution data on average concentrations of nitrogen dioxide $\left(\mathrm{NO}_{2}\right)$ expressed in $\mu \mathrm{mol} / \mathrm{m}^{2}$ were obtained using information provided by the space satellite Sentinel 5 Precursor (S5P), managed by the European Space Agency (ESA) and the European Commission under the Copernicus program [9].

The periods analyzed refer to one baseline period identified before the spread of the epidemic in Italy (February 1 - 24) and to the following weeks (February 24 - March 8, March 8 - 22, March 22 - April 5 and April 5 - 19).

For this study, it was considered the tropospheric vertical column of $\mathrm{NO}_{2}$ reported by ESA Sentinel-5P and made available through high resolution offline (OFFL) image processing of nitrogen dioxide concentrations, obtainable approximately 5 days after detection time [10]. The satellite data therefore comes from the Sentinel-5P OFFL $\mathrm{NO}_{2}$ dataset [15] of the Google Earth Engine API platform [17] through the use of Area of 
Interest (AOI) tools and a simple Python programming code. We obtained a single satellite image defined by the mean of the $\mathrm{NO}_{2}$ concentrations expressed in $\mu \mathrm{mol} / \mathrm{m}^{2}$, for each of the periods considered. The satellite images were downloaded in raster (Geotiff) format, georeferenced according to the World Geodetic System (WGS-1984) and then a population-weighted average was made for the year 2020 of the $\mathrm{NO}_{2}$ values for each individual provinces and regions through the QGIS software. The population data used were obtained from the Gridded Population of the World - Fourth Version (GPWv4) dataset provided by the Center for International Earth Science Information Network (CIESIN) which models the distribution of the global human population consistent with national censuses and population registers, for the years 2000, 2005, 2010, 2015 and 2020 on grid cells of about $1 \mathrm{~km}$ [3]. In addition, we retrieved vertical air flows (omega) at $850 \mathrm{mb}$ (about 1,5 km above sea level) that define the atmospheric capacity to disperse the gas, in order to obtain a better understanding of $\mathrm{NO}_{2}$ concentrations during the period of the event considered. In regions where positive omega is observed, the atmosphere forces the polluted $\mathrm{NO}_{2}$ to remain close to the surface, resulting in increased exposure to the risk factor for the population. On the contrary, in regions with negative omega, atmospheric conditions allow the dispersion of the gas further away and at higher altitudes. Therefore, in these regions there is a lower exposure of the population to air pollution and associated health risks [30]. Data were provided by the NOAA/OAR/ESRL PSD, Boulder, Colorado, USA [29].

\subsection{Epidemiological Data}

The trend data on the number of total positive cases of SARS-CoV-2 infection at regional and provincial level, corresponding respectively to levels 2 and 3 of the Nomenclature of territorial units for statistics (NUTS), were available on the website of the Civil Protection Department [7]. Considering the number of positive cases of COVID-19, prevalence rates per 100.000 inhabitants were obtained using the most up-to-date population data on January 1, 2019, available from the Italian National Institute of Statistic [22]. Prevalence rates were calculated as the ratio of the number of SARS-CoV-2 positive subjects to the total number of individuals in the population during the lock down (as of March 8, March 22, April 5 and April 19 2020).

Finally, in this research an analysis of excess mortality (in percentage values) was carried out, in order to indirectly evaluate the effect of COVID-19 epidemic on total deaths observed during the study period.

The excess mortality data defines the percentage change in deaths at the provincial level recorded in 2020 compared to the average of the previous five years (2015-2019). Clearly, positive values indicate an increase in deaths compared to the previous period considered. Deaths data were available from the European Statistical Office dataset [11], aggregated weekly at provincial level (NUTS 3).

For this analysis, it was chosen the period between the 10th week and the 16th week (March 2 - April 19 2020) because the first COVID-19 deaths in this regions occurred from March 3 to 5 respectively for Liguria and Piemonte, while the Valle d'Aosta has encountered the first deaths only later on March 11 [7]. 


\subsection{Statistical Analysis}

First, an exploratory and descriptive analysis of the dataset used was carried out, which made it possible to investigate the distribution of each variable and the presence of any anomalous values identifiable as outliers.

Second, the relationships between the average levels of $\mathrm{NO}_{2}$ prior to the onset of the Italian epidemic (February 1-24) and the prevalence rates of SARS-CoV-2 infection in the periods March 8 and 22 March, April 5 and 19, 2020 were examined using Spearman's correlation coefficient $(\rho)$. This non-parametric index calculates the relation based not on the values of the two variables but on their ordinal position (ranks). This allows to obtain an index value much less affected by outliers than the Pearson's linear coefficient. Similar to the latter, the Spearman's coefficient provides values between -1 and +1 ; the closer the index is to zero, the weaker the relationship will be, the closer it gets to -1 or +1 the stronger the relationship will be negative or positive.

Spearman's correlation coefficient was also useful for investigating the association between the average levels of $\mathrm{NO}_{2}$ before February 24 and excess mortality data calculated for the period March 2 - April 19, 2020.

Once the functional relationships between the variables under consideration have been established, subsequent exploratory analyses have been carried out with Poisson regression model. Since evidence of overdispersion was observed, we applied quasiPoisson multivariate models. These ones are a generalization of the Poisson regression and they allow to take into account the overdispersion of the data, adjusting the variance according to a specific dispersion parameter [36].

Within the models, some possible confounding factors were considered such as the percentage of the population over the age of 65 and the ratio of females to males, as the incidence of COVID-19 has proven to be higher among men and people 65 years of age or older [21]. In addition, another possible confounding factor taken into account was population density (population $/ \mathrm{km}^{2}$ ); in fact, one would expect the most densely populated provinces to be among the most polluted, due to the social and economic spatial concentration, but also the places where the contagion could have spread more easily with a potential greater impact on the exposed population. These data used were available from the Italian National Institute of Statistic (ISTAT), updated on January 1, 2019 [22].

The estimated coefficients, obtained from quasi-Poisson multivariate regression models, define the size of the variation in the dependent variable (prevalence rates or excess mortality) for a unit increase of the independent variable (defined as a $10 \mu \mathrm{mol} / \mathrm{m}^{2}$ increase in the average concentration of $\mathrm{NO}_{2}$ before February 24).

The data of each variable was collected and organized in table format through Microsoft Excel program and then processed in statistical analysis using RStudio software. 


\section{Results}

\subsection{Analysis of Tropospheric $\mathrm{NO}_{2}$ Concentrations}

Figure 1 shows the geographical distribution at provincial level of the average concentrations of $\mathrm{NO}_{2}$ tropospheric in $\mu \mathrm{mol} / \mathrm{m}^{2}$ weighted on the population for the five periods analyzed, corresponding to before and after the spread of the Italian epidemic.

The average concentrations of $\mathrm{NO}_{2}$ had high values in the first period before the outbreak (February 1 to 24). They were particularly high in the Metropolitan City of Torino $\left(119 \mu \mathrm{mol} / \mathrm{m}^{2}\right)$ and in the province of Novara $\left(118 \mu \mathrm{mol} / \mathrm{m}^{2}\right)$. While, in the following weeks during the spread of the epidemic, there was a drastic reduction in concentrations of polluted, less than $90 \mu \mathrm{mol} / \mathrm{m}^{2}$, in all the provinces analyzed. This reduction is attributable to the containment measures implemented by the government against the spread of COVID-19 disease, which led to a consequent sharp reduction in transportation-related emissions, as well as the decrease in industrial activities and electricity production.
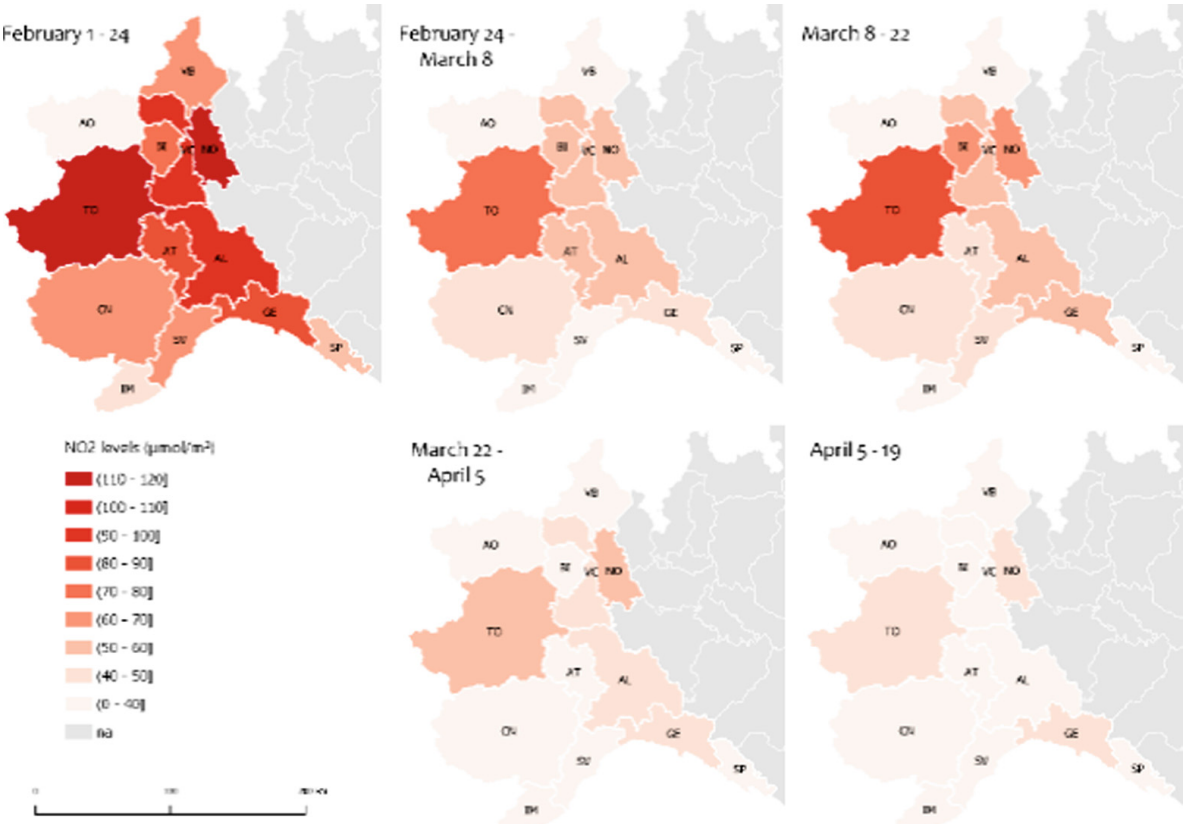

Fig. 1. Study area of North-Western Italy showing the average concentrations of tropospheric $\mathrm{NO}_{2}\left(\mu \mathrm{mol} / \mathrm{m}^{2}\right)$ weighted on the population for the five periods considered in the analysis. 
Key to abbreviations/provinces:

\begin{tabular}{l|l|l|l|l|l|l|l}
\hline AL & Alessandria & CN & Cuneo & NO & Novara & TO & Torino \\
\hline AO & Aosta & GE & Genova & SP & La Spezia & VB & Verbano C.O \\
\hline AT & Asti & IM & Imperia & SV & Savona & VC & Vercelli \\
\hline BI & Biella & & & & & & \\
\hline
\end{tabular}

These concentrations of nitrogen dioxide, for the whole event considered, were also accompanied by vertical downward air flows (positive omega between 0 and $0,02 \mathrm{~Pa} / \mathrm{s}$ ) which prevented the dispersion of the pollutant and increased exposure and risk factors for the population.

\subsection{Relationship Between $\mathrm{NO}_{2}$ Pollution and Prevalence Rates}

Table 1 shows the total number of SARS-CoV-2 positive cases and prevalence rates (per 100.000) calculated over the four time periods considered in the study, i.e. the one corresponding to the establishment of the total block (March 8) and the following weeks (March 22, April 5 and 19). In this table are also reported population data on January 1,2019 with the values of the confounding factors used in the multivariate analysis (females/males, \% population over 65 years old and population density).

Table 1. Total number of positive cases from SARS-CoV-2 and prevalence rates (per 100.000) on March 8, March 22, April 5 and April 19 and population data as of January 1, 2019.

\begin{tabular}{|c|c|c|c|c|c|c|c|c|c|c|c|c|}
\hline & \multicolumn{4}{|c|}{ population (2019) } & \multicolumn{4}{|c|}{ total cases of COVID-19 } & \multicolumn{4}{|c|}{ prevalence rates (per 100.000) } \\
\hline & total & female/male & over $65 \%$ & density* & 08-mar & 22-mar & 05-apr & 19-apr & 08-mar & 22-mar & 05-apr & 19-apr \\
\hline Piemonte & 4.356 .406 & 1,06 & 0,26 & 171 & 360 & 4.420 & 12.362 & 21.057 & 8,3 & 101,5 & 283,8 & 483,4 \\
\hline Torino (TO) & 2.259 .523 & 1,07 & 0,25 & 330 & 89 & 1.989 & 5.985 & 10.144 & 3,9 & 88,0 & 264,9 & 448,9 \\
\hline Vercelli (VC) & 170.911 & 1,06 & 0,27 & 82 & 15 & 242 & 605 & 975 & 8,8 & 141,6 & 354,0 & 570,5 \\
\hline Novara (NO) & 369.018 & 1,05 & 0,24 & 275 & 13 & 398 & 986 & 1.987 & 3,5 & 107,9 & 267,2 & 538,5 \\
\hline Cuneo $(\mathrm{CN})$ & 587.098 & 1,03 & 0,24 & 85 & 5 & 303 & 1.071 & 2.053 & 0,9 & 51,6 & 182,4 & 349,7 \\
\hline Asti (AT) & 214.638 & 1,04 & 0,26 & 141 & 58 & 181 & 596 & 1.064 & 27,0 & 84,3 & 277,7 & 495,7 \\
\hline Alessandria (AL) & 421.284 & 1,06 & 0,28 & 118 & 60 & 760 & 1.763 & 2.783 & 14,2 & 180,4 & 418,5 & 660,6 \\
\hline Biella (BI) & 175.585 & 1,08 & 0,29 & 191 & 19 & 243 & 571 & 783 & 10,8 & 138,4 & 325,2 & 445,9 \\
\hline Verbano C.O. (VB) & 158.349 & 1,06 & 0,27 & 70 & 13 & 159 & 556 & 935 & 8,2 & 100,4 & 351,1 & 590,5 \\
\hline Valle d'Aosta & 125.666 & 1,05 & 0,24 & 38 & 9 & 364 & 782 & 1.088 & 7,2 & 289,7 & 622,3 & 865,8 \\
\hline Liguria & 1.550 .640 & 1,09 & 0,28 & 285 & 78 & 1.665 & 4.449 & 6.528 & 5,0 & 107,4 & 286,9 & 421,0 \\
\hline Imperia (IM) & 213.840 & 1,07 & 0,28 & 185 & 10 & 168 & 586 & 1.122 & 4,7 & 78,6 & 274,0 & 524,7 \\
\hline Savona (SV) & 276.064 & 1,09 & 0,29 & 177 & 25 & 175 & 734 & 926 & 9,1 & 63,4 & 265,9 & 335,4 \\
\hline Genova (GE) & 841.180 & 1,10 & 0,29 & 456 & 25 & 677 & 1.924 & 3.706 & 3,0 & 80,5 & 228,7 & 440,6 \\
\hline La Spezia (SP) & 219.556 & 1,07 & 0,27 & 249 & 11 & 99 & 445 & 767 & 5,0 & 45,1 & 202,7 & 349,3 \\
\hline Italia & 60.359 .546 & 1,05 & 0,23 & 199 & 7.375 & 59.138 & 128.948 & 178.972 & 12,2 & 98,0 & 213,6 & 296,5 \\
\hline
\end{tabular}

The preliminary exploratory analysis of prevalence rates showed very high values that were numerically distant from the rest of the data collected, identifiable as outliers and corresponding to the Valle d'Aosta region. Therefore, the latter was excluded from the subsequent correlation analysis.

The variables have a positive monotone relationship for the periods March 22, April 5, and April 19, as evidenced by the regression lines in the scatter plots in Fig. 2. 

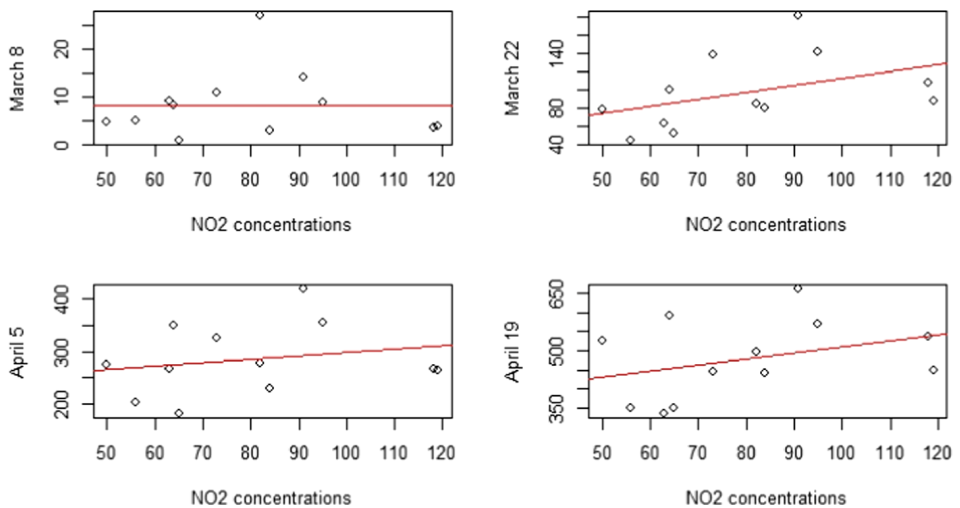

Fig. 2. Scatterplot of correlations between mean $\mathrm{NO}_{2}$ levels before February 24 and prevalence rates $(\mathrm{TP})$.

Sperman's coefficients showed positive correlations between $\mathrm{NO}_{2}$ concentrations before February 24 and prevalence rates for the periods of March 22, April 5 and 19 ( $\rho$ $=0,65$, p-value $<0,05 ; \rho=0,21$ and $\rho=0,40$, p-value $>0,05$, respectively). While a weak negative correlation for the period March $8(\rho=-0,07, \mathrm{p}$-value $>0,05)$ may probably depend on the slowdown in cumulative positive cases of SARS-CoV-2 infection in the studied territories, until that day.

The results of estimates prevalence rate ratio of quasi-Poisson regression models are summarized on a logarithmic scale in the following Table 2 together with the corresponding standard error ( $s e$ ) for the four different periods considered (March 8 and 22, April 5 and 19).

Table 2. Estimates of prevalence rate ratio and the corresponding standard error (se) of quasiPoisson regression models over the four periods considered.

\begin{tabular}{|c|c|c|c|c|c|}
\hline & & $\begin{array}{c}\mathrm{NO}_{2} \\
\text { concentrations }\end{array}$ & $\begin{array}{c}\text { females } \\
\text { /males }\end{array}$ & $\begin{array}{l}\text { \% pop } \\
\text { over65 }\end{array}$ & $\begin{array}{c}\text { population } \\
\text { density }\end{array}$ \\
\hline \multirow{2}{*}{ March 8} & estimated & $1,9 \mathrm{e}-02$ & $-4,4 \mathrm{e}+01$ & $5,7 e+01$ & $-3,9 e-04$ \\
\hline & $(\mathrm{se})$ & $1,2 \mathrm{e}-02$ & $3,1 \mathrm{e}+01$ & $2,5 \mathrm{e}+01$ & $3,6 \mathrm{e}-03$ \\
\hline \multirow{2}{*}{ March 22} & estimated & $2,0 \mathrm{e}-02 * * *$ & $-1,6 \mathrm{e}+01$ & $3,0 \mathrm{e}+01 * *$ & $-9,6 \mathrm{e}-04$ \\
\hline & $(\mathrm{se})$ & $2,8 \mathrm{e}-03$ & $7,2 \mathrm{e}+00$ & $5,7 \mathrm{e}+00$ & $8,0 \mathrm{e}-04$ \\
\hline \multirow{2}{*}{ April 5} & estimated & $1,1 \mathrm{e}-02 * * *$ & $-2,0 \mathrm{e}+00$ & $1,3 \mathrm{e}+01 * *$ & $-0,2 \mathrm{e}-02 *$ \\
\hline & $(\mathrm{se})$ & $1,8 \mathrm{e}-03$ & $4,7 \mathrm{e}+00$ & $3,8 \mathrm{e}+00$ & $5,1 \mathrm{e}-04$ \\
\hline \multirow{2}{*}{ April 19} & estimated & $9,0 \mathrm{e}-03 *$ & $-1,2 \mathrm{e}+01$ & $1,6 \mathrm{e}+01^{*}$ & $1,8 \mathrm{e}-05$ \\
\hline & (se) & $2,6 \mathrm{e}-03$ & $7,2 \mathrm{e}+00$ & $5,8 \mathrm{e}+00$ & $7,9 \mathrm{e}-04$ \\
\hline
\end{tabular}


An increase of 10 units in the concentration of $\mathrm{NO}_{2}$ in $\mu \mathrm{mol} / \mathrm{m}^{2}$ is associated with an increase between $9.5 \%$ and $22 \%(95 \% \mathrm{CI}:-2.6 \div 55)$ on the prevalence rates in the territories analyzed during the first wave of COVID-19.

\subsection{Relationship Between $\mathrm{NO}_{2}$ Pollution and Excess of Mortality}

The analysis of excess mortality for the period March 2 - April 19, 2020 is shown spatially in graphic form in the map in Fig. 3, for all the provinces considered. The map was made taking into account the average $(\mu)$ and the standard deviation $(\sigma)$. Therefore the classes identified are broken down according to the range defined by these two statistical values: lower $(\mathrm{x}<\mu-\sigma)$, low $(\mu-\sigma \leq \mathrm{x}<\mu)$, high $(\mu \leq \mathrm{x}<\mu+\sigma)$ and higher $(\mathrm{x} \geq \mu+\sigma)$.

The excess mortality is evident in all three regions with a significant increase in deaths in the provinces of Alessandria, Vercelli and Biella, respectively with $103 \%$ for the first two and $101 \%$ for the third one. The least affected provinces appear to be Cuneo and Savona, despite an increase in mortality between $43 \%$ and $47 \%$.

Even there, the statistical analysis returned a positive correlation between pollution from $\mathrm{NO}_{2}$ before February 24 and data on excess mortality for the period March 2 April 19, $2020(\rho=0,44, p$-value $>0,05)$, as also evidenced by the regression line of the scatterplot graph in Fig. 4.

The quasi-Poisson multivariate regression model returned the rate ratio estimated (RR) that are shown in the Table 3 with the corresponding standard error (se) values. An increase of 10 units in the concentration of $\mathrm{NO}_{2}$ in $\mu \mathrm{mol} / \mathrm{m}^{2}$ has an estimated association of $4,7 \%(95 \%$ CI: $1,8 \div 7,9)$ on excess mortality over the period March 2 to April 19, 2020 .

March 2 - April 19

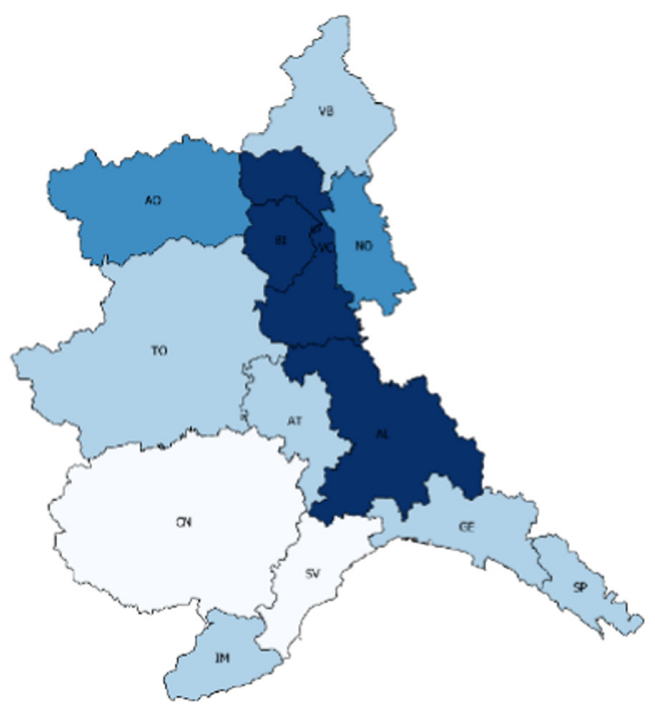

Fig. 3. Excess mortality recorded in the provinces of North-West Italy 


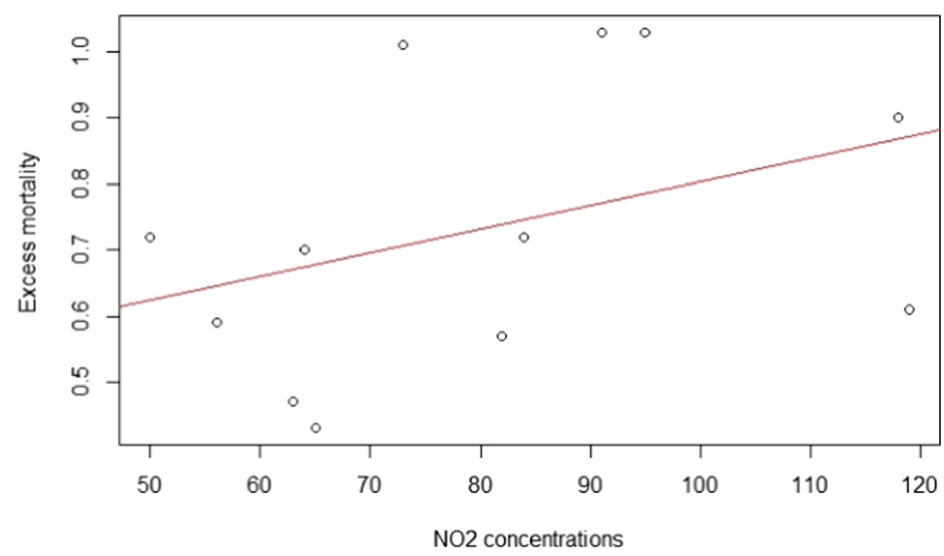

Fig. 4. Scatterplot of correlation between $\mathrm{NO}_{2}$ levels before February 24 and excess mortality.

Table 3. Results of estimates rate ratio and the corresponding standard error (se) of quasi-Poisson regression model for excess mortality data.

\begin{tabular}{lcccc}
\hline & $\begin{array}{c}\mathrm{NO}_{2} \\
\text { concentrations }\end{array}$ & $\begin{array}{c}\text { females } \\
\text { /males }\end{array}$ & $\begin{array}{c}\text { \% pop } \\
\text { over65 }\end{array}$ & $\begin{array}{c}\text { population } \\
\text { density }\end{array}$ \\
\hline estimated & $4,685 \mathrm{e}-03 *$ & $-6,74 \mathrm{e}+00$ & $1,023 \mathrm{e}+01 *$ & $8,2 \mathrm{e}-05$ \\
(se) & $1,496 \mathrm{e}-03$ & $-4,09 \mathrm{e}+00$ & $3,309 \mathrm{e}+00$ & $4,383 \mathrm{e}-04$ \\
\hline$* \mathrm{p}<0,05$ & & & &
\end{tabular}

\section{Conclusion}

The processing of satellite information showed high levels of nitrogen dioxide in $\mu \mathrm{mol} / \mathrm{m}^{2}$ in the pre-epidemic period and a consequent drastic reduction in pollution in the following weeks. In all the provinces considered, this reduction revealed an overall average of $-43 \%$, following the national containment and mitigation measures implemented by the government to deal with the spread of the SARS-CoV-2 virus.

The statistical analysis carried out in this research has allowed to obtain good evidence of the relationship between exposure to nitrogen dioxide $\left(\mathrm{NO}_{2}\right)$ and the COVID-19 epidemic. The relationships turn out to be positive but not significant, as also reflected in the wide confidence intervals $(95 \% \mathrm{CI})$ because the dataset considered has low number and the statistical analysis was carried out with data at aggregate levels that do not allow to consider all the possible confounding factors that influenced the disease epidemic. With reference to the estimates obtained from the multivariate models of quasi-Poisson regression and the confounding factors, no effect related to the relationship between females and males is observed. Whereas it is noted that provinces with a higher share of the population aged 65 and over and with a higher population density were the most affected during the epidemic, as was likely. 
Results from Spearman's correlation coefficients $(\rho)$ and quasi-Poisson's multivariate regression models highlighted the presence of positive relationships between $\mathrm{NO}_{2}$ pollution and the spatial spread of the virus, as well as a positive association between the same concentrations of $\mathrm{NO}_{2}$ and the severity of SARS-CoV-2 infection in 12 of the 13 provinces of North-Western Italy analyzed, excluding Valle d'Aosta. These results are consistent with the emerging literature on the subject [5, 12-14, 23, 27, 30, 32, 44], while biological plausibility gives greater robustness to the positive association observed between the average concentrations of $\mathrm{NO}_{2}$ and the data on excess mortality. In fact, there is clear evidence that the presence of previous diseases can contribute to a more clinically severe forms of COVID-19 and increased mortality from the disease [21, 31, $34,41]$. On the other hand, biological validity is weaker in confirming a potential positive association between polluted nitrogen dioxide and the spatial spread of the virus.

This research project finds possible elements of improvement through the validation of concentrations obtained from satellite information with those collected by ground monitoring stations; analyses carried out with other polluted such as atmospheric particulate matter (PM2,5 and PM10) or tropospheric ozone $\left(\mathrm{O}_{3}\right)$ to investigate their reduction in the period corresponding to lock-down but also to assess their possible contribution to the COVID-19 epidemic; analysis at more detailed scales, referring to individual urban areas or areas defined on mobility data (e.g. local labour systems - SLL); and finally, studies carried out with individual data that consider the individual risk factors that influenced SARS-CoV-2 infection. This allows regression models to be adjusted for all potential confusing factors, so that more robust and important statistical and biological validity can be achieved than those obtained here.

In conclusion, relationships obtained in this research confirm the hypothesis of an important contribution of chronic exposure to air pollution of nitrogen dioxide on the spatial spread and lethality of the SARS-CoV-2 virus. However, there is an awareness that a correlation study at the aggregate level and at the regional and provincial scale cannot identify a real causal link between an exposure and an outcome, but it only suggests a potential association. Therefore, the present work has addressed only a small part of this complex problem and it is appropriate to proceed with further analyzes to better clarify the role of air pollution during the COVID-19 pandemic, which may be useful to activate prevention plans for future health emergencies and encourage and promote sustainable environmental policies.

Acknowledgments. Here we want to thank Giovenale Moirano (MD-PhD, University of Turin) for the precious scientific contribution he has provided us.

\section{References}

1. Bergquist, R., Manda, S.: The world in your hands: GeoHealth then and now. Geospatial Health 14(799), 3-16 (2019). https://doi.org/10.4081/gh.2019.779

2. Carugno, M., Consonni, D., Randi, G., Catelan, D., et al.: Air pollution exposure, causespecific deaths and hospitalizations in a highly polluted Italian region. Environ. Res. 147 (2016). https://doi.org/10.1016/j.envres.2016.03.003 
3. CIESIN. Center for International Earth Science Information Network - Columbia University. Gridded Population of the World, Version 4 (GPWv4): Population Count, Revision 11. Palisades, NY: NASA Socioeconomic Data and Applications Center (SEDAC) (2019). Accessed 18 June 2020. https://doi.org/10.7927/H4JW8BX5

4. Coccia, M.: Factors determining the diffusion of COVID-19 and suggested strategy to prevent future accelerated viral infectivity similar to COVID. Sci. Total Environ. 729 (2020). https:// doi.org/10.1016/j.scitotenv.2020.138474

5. Coker, E.S., et al.: The effects of air pollution on COVID-19 related mortality in Northern Italy. Environ. Resource Econ. 76(4), 611-634 (2020). https://doi.org/10.1007/s10640-02000486-1

6. Conticini, E., Frediani, B., Caro, D.: Can atmospheric pollution be considered a cofactor in extremely high level of SARS-CoV-2 lethality in Northern Italy? Environ. Pollution 261 (2020). https://doi.org/10.1016/j.envpol.2020.114465

7. CPD, Civil Protection Department - official data on COVID-19. https://github.com/pcmdpc/ COVID-19. Accessed 14 July 2020

8. Dlamini, S.N., Beloconi, A., Mabaso, S., Vounatsou, P., Impouma, B., Fall, I.S.: Review of remotely sensed data products for disease mapping and epidemiology. Remote Sensing Appl. Soc. Environ. 14, 108-118 (2019). https://doi.org/10.1016/j.rsase.2019.02.005

9. ESA, European Space Agency - Sentinel-5P information. https://sentinel.esa.int/web/sentinel/ missions/sentinel-5p. Accessed 15 June 2020

10. Eskes, H., van Geffen, J., Boersma, F., et al.: Sentinel-5 Precursor/TROPOMI Level 2 Product User Manual Nitrogen dioxide. Royal Netherlands Meteorological Institute (Ed.) (2019)

11. EUROSTAT, European Statistical Office - dataset. https://ec.europa.eu/eurostat/data/dat abase. Accessed 3 Aug 2020

12. Fattorini, D., Regoli, F.: Role of the chronic air pollution levels in the Covid-19 outbreak risk in Italy. Environ. Pollution 264 (2020). https://doi.org/10.1016/j.envpol.2020.114732

13. Filippini, T., et al.: Associations between mortality from COVID-19 in two Italian regions and outdoor air pollution as assessed through tropospheric nitrogen dioxide. Sci. Total Environ. (2020). https://doi.org/10.1016/j.scitotenv.2020.143355

14. Filippini, T., Rothman, K.J., Goffi, A., Ferrari, F., Maffeis, G., Orsini, N., Vinceti, M.: Satellitedetected tropospheric nitrogen dioxide and spread of SARS-CoV-2 infection in Northern Italy. Sci. Total Environ. 739 (2020). https://doi.org/10.1016/j.sci-totenv.2020.140278

15. GEE, Google Earth Engine - Sentinel-5P OFFL NO 2 dataset. https://developers.google.com/ earth-engine/datasets/catalog/COPERNICUS_S5P_OFFL_L3_NO2. Accessed 15 June 2020

16. Giulianelli, L., et al.: Fog occurrence and chemical composition in the Po valley over the last twenty years. Atmos. Environ. 98, 394-401 (2014). https://doi.org/10.1016/j.atmosenv.2014. 08.080

17. Gorelick, N., Hancher, M., Dixon, M., Ilyushchenko, S., Thau, D., Moore, R.: Google earth engine: planetary-scale geospatial analysis for everyone. Remote Sens. Environ. 202, 18-27 (2017). https://doi.org/10.1016/j.rse.2017.06.031

18. Hay, S.I., Randolph, S., Rogers, D.: Remote sensing and geographical information systems in epidemiology. Advances in Parasitology (47). Academic Press (2000)

19. Hay, S.I., Battle, K.E., Pigott, D.M., Smith, D.L., Moyes, C.L., Bhatt, S., et al.: Global mapping of infectious disease. Philosophical Trans. Roy. Soc. B Biol. Sci. 368(1614) (2013). https:// doi.org/10.1098/rstb.2012.0250

20. Herbreteau, V., Salem, G., Souris, M., Hugot, J.-P., Gonzalez, J.-P.: Thirty years of use and improvement of remote sensing, applied to epidemiology: from early promises to lasting frustration. Health Place 13(2), 400-403 (2007). https://doi.org/10.1016/j.healthplace.2006. 03.003 
21. ISS, Italian National Institute of Health - Characteristics of patients who died positive for SARS-CoV-2 infection in Italy. Data on 20 March 2020. https://www.epicentro.iss.it/corona virus/sars-cov-2-decessi-italia. Accessed 2 Nov 2020

22. ISTAT, Italian National Institute of Statistic - official data. https://www.istat.it/it/popolazionee-famiglie. Accessed 15 July 2020

23. Jiang, F., Deng, L., Zhang, L., Cai, Y., Cheung, C.W., Xia, Z.: Review of the clinical characteristics of coronavirus disease 2019 (COVID-19). J. Gen. Intern. Med. 35(5), 1545-1549 (2020). https://doi.org/10.1007/s11606-020-05762-w

24. Jones, K.E., et al.: Global trends in emerging infectious diseases. Nature 451(7181), 990-993 (2008). https://doi.org/10.1038/nature06536

25. Kraemer, M.U.G., Hay, S.I., Pigott, D.M., Smith, D.L., Wint, G.R.W., Golding, N.: Progress and challenges in infectious disease cartography. Trends Parasitol. 32(1), 19-29 (2016). https://doi.org/10.1016/j.pt.2015.09.006

26. Larsen, B., Gilardoni, S., Stenström, K., Niedzialek, J., Jimenez, J., Belis, C.: Sources for PM air pollution in the Po Plain, Italy: II. Probabilistic uncertainty characterization and sensitivity analysis of secondary and primary sources. Atmospheric Environ. 50, 203-213 (2012). https:// doi.org/10.1016/j.atmosenv.2011.12.038

27. Li, H., Xu, X.-L., Dai, D.-W., Huang, Z.-Y., Ma, Z., Guan, Y.-J.: Air pollution and temperature are associated with increased COVID-19 incidence: a time series study. Int. J. Infect. 97, 278-282 (2020). https://doi.org/10.1016/j.ijid.2020.05.076

28. Martelletti, L., Martelletti, P.: Air pollution and the novel Covid-19 disease: a putative disease risk factor. SN Compr. Clin. Med. 2(4), 383-387 (2020). https://doi.org/10.1007/s42399-02000274-4

29. NOAA, National Oceanic and Atmospheric Administration - Physical Sciences Laboratory (PSL) dataset. http://www.esrl.noaa.gov/psd/. Accessed 23 July 2020

30. Ogen, Y.: Assessing nitrogen dioxide $\left(\mathrm{NO}_{2}\right)$ levels as a contributing factor to coronavirus (COVID-19) fatality. Science of The Total Environment, 7269 (2020). https://doi.org/10. 1016/j.scitotenv.2020.138605

31. Onder, G., Rezza, G., Brusaferro, S.: Case-fatality rate and characteristics of patients dying in relation to COVID-19 in Italy. JAMA 323, 1775-1776 (2020). https://doi.org/10.1001/jama. 2020.4683

32. Pansini, R., Fornacca, D.: COVID-19 higher induced mortality in Chinese regions with lower air quality. medRxiv (2020). https://doi.org/10.1101/2020.04.04.20053595

33. Pozzer, A., Bacer, S., Sappadina, S.D.Z., Predicatori, F., Caleffi, A.: Long-term concentrations of fine particulate matter and impact on human health in Verona. Italy. Atmospheric Pollution Res. 10, 731-738 (2019). https://doi.org/10.1016/j.apr.2018.11.012

34. Reilev, M., et al.: Characteristics and predictors of hospitalization and death in the first 11.122 cases with a positive RT-PCR test for SARS-CoV-2 in Denmark: a nationwide cohort. Int. J. Epidemiology (2020). https://doi.org/10.1093/ije/dyaa140

35. RIAS, Rete Italiana Ambiente e Salute - Inquinamento atmosferico e COVID-19. Accessed date: 18 October 2020. https://www.scienzainrete.it/articolo/inquinamento-atmosferico-ecovid-19/reteitaliana-ambiente-e-salute/2020-04-13

36. Richard, B., MacDonald, J.M.: Overdispersion and poisson regression. J. Quant. Criminol. 24, 269-284 (2008). https://doi.org/10.1007/s10940-008-9048-4

37. Schneider, M.C., Machado, G.: Environmental and socioeconomic drivers in infectious disease. Lancet Planet. Health 2(5), 198-199 (2018). https://doi.org/10.1016/S2542-519 6(18)30069-X

38. Setti, L., Passarini, F., Gennaro, G.D., et al.: Potential role of particulate matter in the spreading of COVID-19 in Northern Italy: first observational study based on initial epidemic diffusion. BMJ J. 10 (2020). https://doi.org/10.1136/bmjopen-2020-039338 
39. Shaw, N., McGuire, S.: Understanding the use of geographical information systems (GIS) in health informatics research: a review. J. Innov. Health Inf. 24(2), 228-233 (2017). https://doi. org/10.14236/jhi.v24i2.940

40. SIMA, Società Italiana di Medicina Ambientale: Particulate matter and COVID-19 - Position paper, (2020). http://www.simaonlus.it/wpsima/wp-content/uploads/2020/03/COVID_ 19_position-paper_ENG.pdf. Accessed 18 Oct 2020

41. Ssentongo, P., Ssentongo, A.E., Heilbrunn, E.S., Ba, D.M., Chinchilli, V.M.: Association of cardiovascular disease and 10 other pre-existing comorbidities with COVID-19 mortality: a systematic review and meta-analysis. PLoS One 15 (2020). https://doi.org/10.1371/journal. pone. 0238215

42. Suk, J.E., Semenza, J.C.: Future infectious disease threats to Europe. Am. J. Public Health 101(11), 2068-2079 (2011). https://doi.org/10.2105/AJPH.2011.300181

43. Viana, J., et al.: Remote sensing in human health: a 10-year bibliometric analysis. Remote Sens. 9(12), 1225 (2017). https://doi.org/10.3390/rs9121225

44. Zoran, M.A., Savastru, R.S., Savastru, D.M., Tautan, M.N.: Assessing the relationship between ground levels of ozone $\left(\mathrm{O}_{3}\right)$ and nitrogen dioxide $\left(\mathrm{NO}_{2}\right)$ with coronavirus (COVID19) in Milan, Italy. Sci. Total Environ. 740 (2020). https://doi.org/10.1016/j.scitotenv.2020. 140005

Open Access This chapter is licensed under the terms of the Creative Commons Attribution 4.0 International License (http://creativecommons.org/licenses/by/4.0/), which permits use, sharing, adaptation, distribution and reproduction in any medium or format, as long as you give appropriate credit to the original author(s) and the source, provide a link to the Creative Commons license and indicate if changes were made.

The images or other third party material in this chapter are included in the chapter's Creative Commons license, unless indicated otherwise in a credit line to the material. If material is not included in the chapter's Creative Commons license and your intended use is not permitted by statutory regulation or exceeds the permitted use, you will need to obtain permission directly from the copyright holder.

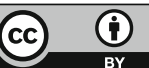

